УДК 378.147. 614

ІРИНА ДУБКОВЕЦЬКА, асистент кафедри фізіологіi Івано-Франківського національного медичного університету, м. Івано-Франківськ, Украӥна idubkovetska@yahoo.com ORCID ID 0000-0003-4854-8529

\title{
РОЗВИТОК ПРОФЕСІЙНОЇ КОМПЕТЕНТНОСТІ МАЙБУТНІХ МЕДИЧНИХ ПРАЦІВНИКІВ В УМОВАХ ЄВРОІНТЕГРУВАННЯ
}

\author{
IRYNA DUBKOVETSKA, assistant of the Department of \\ Physiology, Ivano-Frankivsk National Medical University, \\ Ivano-Frankivsk, Ukraine
}

\section{DEVELOPMENT OF PROFESSIONAL COMPETENCE OF FUTURE MEDICAL WORKERS IN THE CONDITIONS OF EUROPEAN INTEGRATION}

\begin{abstract}
У статті автор аналізує теоретичні основи формування професійної компетентності майбутніх медичних працівників, виокремлює напрацювання науковців, що торкаються різних аспектів означеної проблеми. Зазначено, що професійна підготовка майбугніх медичних працівників на сучасному етапі розвитку повинна базуватися на гуманістичній теорії та прагненні особистості до самоосвіти, самовдосконалення і самореалізації. Акцентується на потребі системного підходу до професійної підготовки майбутніх медиків, концептуального осмислення основних завдань про-

професійної діяльності, що виявляється у досконалому здійсненні та стабільно високих результатах медичної практики, здатності до професійної самоорганізації, самоактуалізації, професійного саморозвитку. Наголошено, що основною умовою розвитку особистості майбутнього медичного працівника на сучасному етапі виступає переорієнтація освітнього процесу ЗВМО з вузькопредметного характеру вивчення навчальних дисциплін на розвиток професійно зорієнтованого, критичного осмисленого; розвиток творчого потенціалу особистості.
\end{abstract} фесійного розвитку особистості, їх реалізації упродовж життя. Розкрито особливості професійної підготовки майбутніх медичних працівників, виокремлено основні напрями внесення змін і коректив щодо навчання у закладах вищої освіти. Основна увага приділяється компетентнісному підходу в освітньому процесі, аналізу позитивних результатів професійної підготовки внаслідок його впровадження узакладах вищої медичної освіти (ЗВМО). Уточнено сутність понять "компетентність", "професійна компетентність", "професіоналізм", "базові якості"; визначено структурні ії компоненти та ознаки; етапи щодо формування у процесі професійної підготовки. Основну увагу закцентовано на професіоналізмі як віддзеркаленні професійної компетентності, цілісній інтегративній характеристиці суб'єкта

(C) I. Дубковецька
Ключові слова: майбугній медичний працівник, професійний розвиток, професійна компетентність, компетентнісний підхід, самоосвіта.

Summary. In the article the author analyzes the theoretical bases of formation of professional competence of future medical professionals, highlights the work of scientists concerning the different aspects of the problem. It is stated that the professional training of future medical professionals at the current stage of development should be based on humanistic theory and the desire of the person for selfeducation, self-improvement and selfrealization. The author focuses on the necessity for a systematic approach concerning the professional training of future physicians, a conceptual understanding of the main tasks of professional development of the person and their implementation throughout life. The peculiarities of professional training of future medical workers are revealed, the main directions of making changes and adjustments concerning the education in higher educational institutions are highlighted. The focus is on the competency-based approach in the educational process, the analysis of the positive results of the professional training as a result of its implementation in the institutions of higher medical education (IHME). The essence of the concepts "competence", "professional competence", "professionalism", "basic qualities" are clarified; its structural components and features are identified; stages concerning the formation in the process of professional training. The main attention is focused on professionalism as a reflection of professional competence, a holistic integrative characteristic of the subject of professional activity, which is manifested in perfect implementation and consistently high results of medical practice, ability to professional selforganization, self-actualization, professional self-development. It is emphasized that the main condition for the development of the personality of the future health care worker at the present stage is the re-orientation of the educational process of IHME from the narrow-subject nature of the study of educational disciplines onto the development of professionally-oriented, critical thinking; development of the creative potential of the person.

Key words: future medical specialist, professional development, professional 
competence, competence approach, self-education.

Мета: проаналізувати теоретичні основи розвитку професійної компетентності майбутніх медичних працівників в умовах євроінтегрування.

Постановка проблеми в загальному вигляды. В умовах сьогодення особливий акцент ставиться на збереження здоров'я нації, українського народу, народів світу загалом. Саме тому проблема формування медичного працівника як фахівця нової епохи потребує негайного її вирішення. У центрі уваги - розвиток професійної компетентності майбутнього фахівця, що являє собою сукупність знань, умінь та навичок, які вможливлюють надання ним якісних медичних послуг 3 метою "збереження та відновлення фізіологічних і психологічних функцій, оптимальної працездатності та соціальної активності людини при максимальній біологічно можливій індивідуальній тривалості ііі життя" (Закон Украйни "Про внесення змін...", 2017).

В умовах євроінтегрування істотно підвищуються вимоги до системи охорони здоров'я та професійної підготовки фахівців медичної сфери, які повинні бути готовими до впровадження нових медичних реформ. Як засвідчують сучасні реалії щодо поширення коронавірусу, працівники медичної сфери повинні бути максимально гнучкими й мобільними щодо аналізу наявної ситуації, прийняття відповідальних рішень, упровадження інновацій у медичній практиці. Це значною мірою стосується підготовки майбутніх медиків на засадах компетентнісного підходу, за якого студенти опановують необхідні знання i цінності, професійні вміннями і навички. Це уможливлює правильні та швидкі дії у нестандартних ситуаціях, самостійність уприйнятті рішень, виявлення ініціативи тощо. На цьому наголошується в основних нормативних документах про освіту та реформування медичної галузі в Україні.

Аналіз досліджень і публікацій. До питання професійної підготовки майбутніх медичних працівників неодноразово звертались науковці, лікаріпрактики, намагаючись виокремити основні шляхи підвищення ефективності професійного становлення особистості (М. Банчук, О. Волосовець, Н. Гойда, П. Гощинський, Г. Загричук, T. Калюжна, Г. Крицька, I. Крицький, В. Лазоришинець, В. Лехан, Л. Матю- ха, О. Мочульська, В. Сірик та інші. Фахівці одностайні в тому, що проблему професійного розвитку особистості варто розглядати у двох аспектах: по-перше, як неперервну освіту особистості, мета якої всебічний їі розвиток; по-друге, професійну освіту, в основі якої підготовка майбутнього фахівця медичної галузі, здатного до якісної практичної діяльності заради збереження здоров'я людей та попередження можливих захворювань.

3 іншого боку, сучасному фахівцю медичної сфери у процесі професійної підготовки варто сформувати в собі триєдиний стержень, в основі якого:

1) фахівець (знання медичної теорії і психології, практичного досвіду, володіння необхідними технологіями і техніками);

2) медичний працівник (уміння визначати мету і досягати поставлених цілей у процесі практичної діяльності; систематичне і планомірне підвищення кваліфікації; самоосвітня діяльність; спрямованість на підвищення продуктивності медичної практики; розвиток професійних здібностей);

3) особистість (гуманізм та високі моральні якості, духовність, національна гідність, здоровий спосіб життя тощо).

Виклад основного матеріалу дослідження. Головна мета професійної підготовки майбутніх медичних працівників на сучасному етапі полягає в упровадженні інновацій, кращих європейських освітніх практик (Budnyk, 2019), створенні умов неперервної освіти на основі новітніх технологій; вивченні, узагальненні та застосуванні прогресивного медичного досвіду упрактичній діяльності; мотивації до самонавчання та саморозвитку. Ідеться, передусім, про підготовку висококваліфікованого фахівця сфери охорони здоров'я на засадах гуманізму і практико орієнтованого підходу, стимулювання до самоосвіти, самовдосконалення та саморозвитку впродовж життя.

Національна система підготовки медичних працівників зорієнтована на оволодіння майбутніми фахівцями системою знань, засвоєння зовнішніх вимог, спеціальних умінь і навичок. Окрім належного рівня теоретичної підготовки, основним інструментом роботи сучасного медика має виступати його власна особистість: моральні цінності, світогляд та переконання, самооцінка, мотивація до впро- вадження інновацій тощо. Інструментом модернізації освіти стає компетентнісний підхід, який "орієнтується на професійну компетентність як якість особистості майбутнього фахівця, що характеризує рівень його інтеграції у середовище професійної діяльності, як і в різні соціальні середовища, входження в які виявляє необхідність виконувати різні соціальні ролі" (Вознюк, 2011, с. 14).

Поняття "компетентний" (від лат. competes, від compete - належний, здатний) у довідниках трактується як "той, що володіє знаннями, який має право за своїми знаннями і повноваженнями робити або вирішувати що-небудь, судити про що-небудь" (Академічний тлумачний словник, 1973). Компетентність виступає здатністю виконувати поставлені завдання, включаючи поняття якісних характеристик особистості (мобільності, ініціативності, креативності тощо). У працях науковців компетентність розглядається як прояв професіоналізму, пов'язаний 3 подальшою оцінкою чи вимірюванням кінцевого результату діяльності фахівця. Зокрема, учені співвідносять професіоналізм з різними аспектами зростання фахівця, виокремлюючи низку його компетентностей.

Досвід моделювання компетентностей Західної Європи, який відображено в напрацюваннях науковців (Н. Хомського - Массачусетський університет, Дж.Равена - Лондон) засвідчує про те, що модель сучасного фахівця повинна включати декілька компетентностей. Так, у матеріалах Ради Європи (1990) виокремлено такі з них: політичні і соціальні; міжкультурні, комунікативні, ІКТ-компетенції та компетенції щодо самоосвіти. Позаяк реалізація медичної реформи в Україні передбачає аналіз та впровадження кращого досвіду європейських держав, слід виділити основні з них, що визначені у професійній освіті країн Свропейського Союзу (Рекомендація Європейського Парламенту.., 2016):

соиіальна компетенція-здатність брати на себе відповідальність, спільно вирішувати та брати участь у реалізації завдань; уміння поєднувати особисті інтереси з потребами підприємства і суспільства; гуманізм, толерантність до різних етнокультур та релігій;

соичіально-інформачійна компетенція - володіння інформаційними технологіями і критичне мислення фахівця;

когнітивна компетенція - го- 
товність до неперервної самоосвіти, потреба в реалізації особистісного потенціалу, уміння і навички самоосвіти, систематичний саморозвиток;

комунікативна компетениія-володіння технологіями спілкування різними мовами; здатність особистості будувати власну мовленнєву поведінку відповідно до реальних ситуацій спілкування, передусім професійного;

спеціальна компетенція - рівень підготовленості фахівця до самостійного виконання професійних дій, оцінки та аналізу власних результатів практичної діяльності тощо.

За такого підходу компетентний медичний працівник повинен бути всебічно розвиненою, високо професійною особистістю, котра володіє не лише системою спеціальних знань, умінь і навичок, а й здатністю діяти в конкретній ситуації, будувати комунікацію 3 пацієнтами та колегами, здійснювати ефективну професійну діяльність, використовувати інновації задля оптимізації медичної практики, професійного та особистісного розвитку. Стрижневі компетентності, які має поєднувати в собі майбутній медичний працівник, включають: соціальну (рольова ідентифікація, комунікативні здібності, організаторські здібності, емпатія, стиль поведінки у нестандартних, конфліктних ситуаціях); професійну (особистісна зрілість, професійна майстерність, здатність до самоосвіти та професійного розвитку, особисті досягнення, здібності до інноваційної діяльності, ерудиція й досконале володіння професійними знаннями); загальнокультурну (стиль практичної діяльності, ціннісні орієнтації, уміння і навички, толерантність, імідж); здоров'язберігаючу (фізичне, психічне, соціальне та духовне здоров'я); компетентність з інформаційних та комунікативних технологій (комп'ютерна грамотність, інформаційна культура як потреба проведення реформи медичної галузі) (Крамарен$\kappa о, 2010)$. Відтак професійна компетентність виступає як сукупність особистісних якостей, знань, умінь та навичок, досвіду, що забезпечують високий рівень самоорганізації професійної діяльності медичного працівника, досягнення високих ії результатів.

Поняття "професійна компетентність" увійшло в термінологію у 80-ті роки ХХ ст. з праць Ю. Бабанського, С. Баранова та В. Сластьоніна i вважалось складовою професіоналізму фахівця. На сучасному етапі "про- фесійна компетентність" є доволі вживаним терміном серед науковців і часто розглядається як поглиблене знання, стан адекватного виконання завдань і здібність до виконання певного виду діяльності. Так, низка науковців (Т. Браже, Н. Запрудський) під професійною компетентністю розуміють системне явище, яке містить знання, уміння, навички, професійно значущі якості особистості фахівця, що забезпечують виконання ним професійного обов'язку. Інші дослідники (Р. Гуревич, Н. Ничкало) вважають, що професійна компетентність - це сукупність та особлива організація знань і вмінь, яка дозволяє успішно діяти у своїй галузі за будь-яких умов, уміння використовувати інформацію, аналізувати та передбачати наслідки своєї праці. В. Кошель зауважує: "Студент повинен володіти необхідною теоретичною інформацією, по-друге, бути здатним застосовувати їх на практиці, по-третє, довести ці знання і вміння до автоматизму..." (Кошель, 2015). На думку О. Савченко: "Формування професійної компетентності у вищому медичному навчальному закладі слід розглядати як процес оволодіння стійкими, інтегрованими, систематизованими знаннями $з$ природничогуманітарних, фундаментальних та клінічних дисциплін; уміння застосовувати їх у нових, нестандартних ситуаціях; розвиток особистісних якостей і професійно важливих властивостей, що забезпечить особистісне становлення майбутнього лікаря" (Савченко, 2010). Отож, професійна компетентність - це "інтегративна характеристика ділових і особистісних якостей фахівця, що відображає рівень знань, умінь, досвіду, достатніх для досягнення мети з певного виду професійної діяльності, а також моральну позицію фахівця" (Енциклопедія освіти, 2008).

У контексті нової освітньої парадигми професійна компетентність визначається не лише як загальна культура, суспільно-економічна поінформованість чи система знань, умінь i навичок, а й уміння мобілізувати отримані знання та досвід у необхідне русло задля вирішення завдань, нестандартних ситуацій тощо. Професійна компетентність майбутнього медичного працівника - показник теоретичної і практичної підготовки студента на основі ключових рис та якостей особистості в поєднанні із сформованими професійними знаннями, уміннями та навичками, ціннісними орієнтаціями, відповідним рівнем мовленнєвої культури (Кошель, (2015). Натомість вона передбачає аналітичні, прогностичні, проєктувальні його здібності, що дозволяють ефективно здійснювати професійну діяльність. Окрім того, професійна компетентність відіграє важливу роль у соціальному та професійному житті індивіда. Особисті риси (упевненість у власних силах, віра в успіх, відповідальність та ініціативність, працьовитість i цілеспрямованість, сміливість, завзятість, толерантність тощо) вважаються ключовими аспектами професійної компетентності (puc. 1).

Дослідники О. Вознюк та О. Дубасенюк наголошують, що "професійна компетентність $€$ здатністю особистості здійснювати професійну діяльність на основі набутих професійних компетенцій, які сприяють розвитку творчого потенціалу особистості, її професійному саморозвитку та самовдосконаленню" (Вознюк \& Дубасенюк, 2011). В. Кульчицький визначає професійну компетентність складовою соціалізації особистості, оскільки "вибір професії та фомування професійних здібностей пов'язані 3 соціально-моральним вибором особистості та роздумами про сенс життя" (Кульчицький, 2012). А тому вчений виокремлює основні етапи формування професійної компетентності студента-медика, а саме:

I eman - вибір професії, прояв епізодичного інтересу, предметна установка;

II етап - стійкі інтереси, прояв зацікавлення до практичної сторони навчального процесу; самостійність, формування почуття відповідальності;

III eman - усталена установка щодо професійного вибору, вияв захоплення медичною практикою, вивченням теоретичних основ медичних наук, самоствердження особистості;

IV eman - загальне захоплення професією, вияв та розвиток здібностей та професійних задатків, наявність професійного ідеалу, стійке переконання у значущості професії (Кульчицький, 2012).

Серед науковців існує думка, що професійна компетентність майбутнього медичного працівника відображає сформованість діагностичної, клінічної та профілактичної компетентностей. Зокрема, вона включає такі складові, як: 1) інтелектуальна; 2) діяльнісна; 3) суб'єктна (саморефлексія, са- 


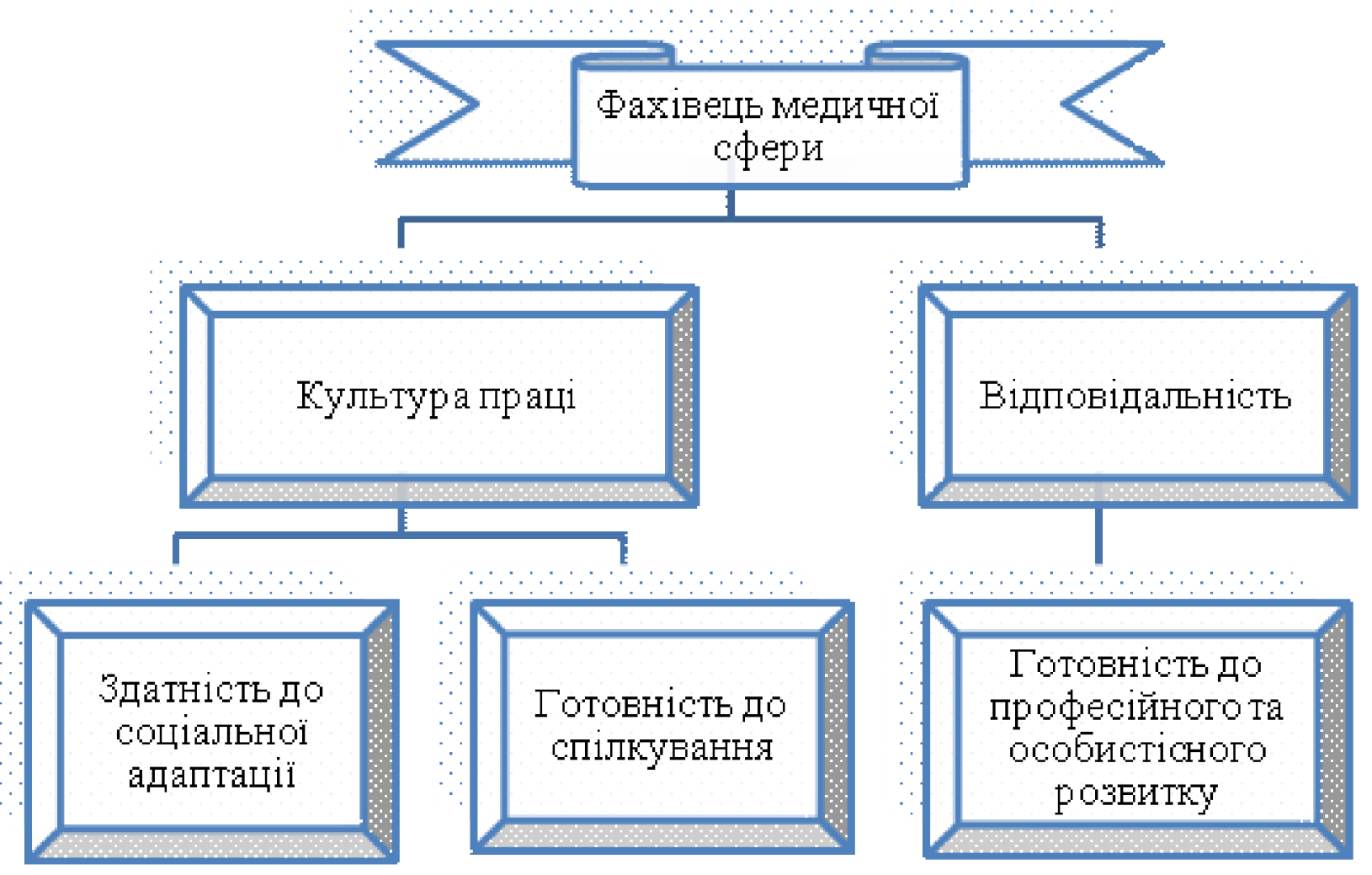

\section{Рис.1. Базовіякостілайбутньогояедичногопрацівника}

морегуляція, самодетермінація). Остання є їі інтегральним компонентом i демонструє рівень активності фахівця, без формування якої реалізація інших складових буде неможливою. Так, структура суб'єктної складової передбачає: актуалізацію суб'єктних проявів у професійній компетентності; напрацювання завдань самореалізації у майбутній професійній діяльності особистістю (прогнозовані результати діяльності, виокремлення шляхів їх досягнення, основних етапів самореалізації); самореалізація у конкретних видах діяльності (побудова та здійснення дій відповідно до поставлених завдань і плану); аналіз й оцінка результатів самореалізації (виокремлення результатів самореалізації, аналіз виокремлених результатів із запланованими, виокремлення прогалин у ході медичної практики; планування шляхів реалізації досягнутого).

Означене вище дозволяє виділити основні складники професійної компетентності майбутнього лікаря, а саме: інформаційні; проєктувальні; аналітичні; комунікативні; соціальні. Унаслідок специфіки професійної діяльності та виконання медичним працівником різних видів роботи (профілактична, діагностична, прак- тична) виникає необхідність формування цих складових професійної компетентності, що загалом дозволяє якісно та ефективно здійснювати медичну практику (рис. 2).

Чільне місце у змісті професійної компетентності посідають знання (загальні, професійні), уміння і навички (комунікативні, професійні, дослідницькі та наукові), особисті якості (почуття відповідальності та професійного обов'язку, милосердя, щирість, сміливість, креативність, толерантність, тактовність, готовність до здійснення професійної діяльності (Крицький, Гощиинський та ін., 2018, c. 45). Такий факт пояснюємо тим, що серед основних шляхів відродження національної системи медичних послуг пріоритетними є творча самореалізація, підвищення професіоналізму, формування здатності динамічно реагувати на запити та виклики часу, оволодівати передовими технологіями практики. 3 іншого боку, це потребує розвитку професійно мобільного медичного працівника, здатного до зміни видів діяльності, використання системи професійно узагальнених прийомів для виконання будь-яких завдань. Засадничими підвалинами професійного становлення майбутніх медичних працівників, як зазначають науковці (I. Крицький, П. Гощинський, Т. Крицький, І. Горішній, О. Мочульська, Г. Крицька) виступають психолого-педагогічні умови формування професійної компетентності та її складові: "Блок-компонент професійної компетентності - мікромодель, яка відображає прогнозований кінцевий результат професійної підготовки студента - професійну компетентність майбутнього лікаря" (Там само).

Професійна підготовка майбутніх фахівців у закладах вищої освіти завжди була в центрі уваги науковців, якот: Б. Ананьєва, І. Кона, В. Лісовського, М. Нечаєва, Г. Різницької. Сьогодні проблему розвитку професійної компетентності досліджують: О. Будник, А. Василюк, Г. Васянович, М. Вачевський, І. Каленюк, Я. Кодлюк, О. Овчарук, О. Садівник, Г. Терещук та інші. Учені виокремлюють потребу підвищення якості професійної підготовки майбутніх фахівців та вказують на шляхи її розв'язання, а саме: перегляд державних вимог до змісту професійної підготовки; підвищення рівня ключових фахових компетенцій; удосконалення освітніх технологій; урахування потреби в міждисциплінарному характері професійної підготовки; поси- 


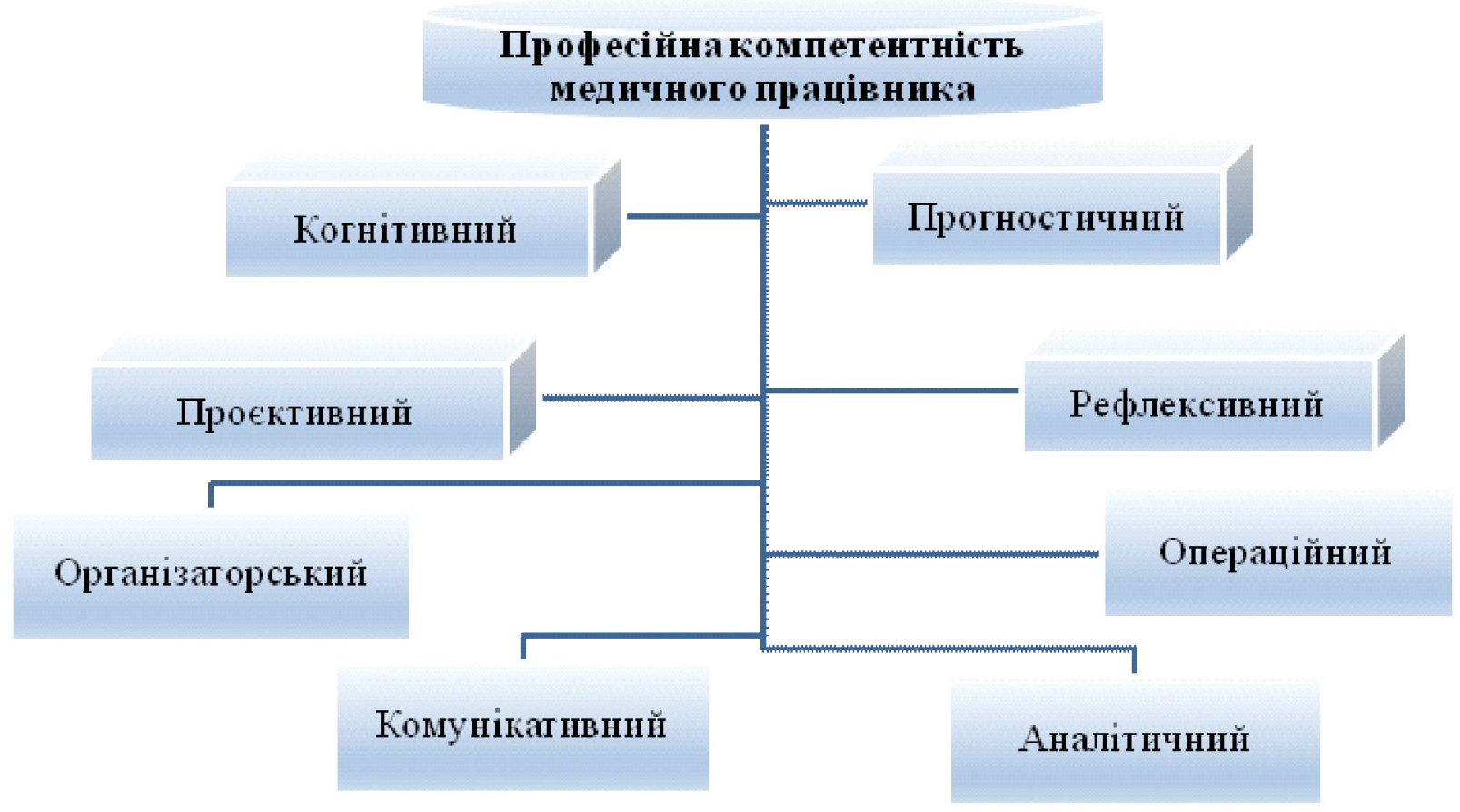

Рис. 2. Складники професійної компетентності майбутнього медичного працівника

лення практичної спрямованості дисциплін, оптимальне використання їх виховного потенціалу та інше. На міркування науковців, якість професійної підготовки тісно пов'язана, з одного боку, з інноваціями, розвитком науки і техніки, а з іншого - з асигнуваннями 3 боку держави: високий відсоток вкладень слугує підвищенню ефективності професійної підготовки майбутніх фахівців. Відтак ефективність формування професійної компетентності можемо визначати й через рівень демократичності суспільства, а отже, навчання у ЗВМО має базуватись на принципі студентоцентризму, індивідуального підходу; бути зорієнтованим на формування та розвиток самодостатньої, талановитої, унікальної особистості. Професійна компетентність як результат професійної підготовки виявляється у використанні набутих знань, умінь і навичок, пристосуванні до умов життя, праці, самореалізації. О. Куклін визначає її як граничну індивідуальну, що для кожної окремо взятої особистості може виражатись у задоволенні іiі внутрішніх потреб, підвищенні рівня доходів, соціального статусу (Куклін, 2008, с. 198). Це дає підстави виокремити внутрішню, що визначається рівнем успішності навчання, та зовнішню професійну підготовку, яку віддзеркалює рівень кваліфікації фахівців, їх адаптованість до подаль- шої життєдіяльності.

Взаємозв'язок професійної компетентності та адаптації до умов життя, самореалізації особистості характеризує рівень якості життя особистості. На цьому наголошували науковці, лікаріпрактики, вивчаючи різні аспекти проблеми: а) готовність особистості до подальшої професійної діяльності (О. Виговська, А. Линенко), професійно-творчий саморозвиток майбутніх фахівців (П. Кравчук, О. Лук, Ю. Фокін) тощо. Професійна компетентність, як вважають учені, торкається й іншого вектора - потреби зміцнення професійного статусу фахівців шляхом економічного регулювання молодіжної зайнятості; докорінної реформи медичної галузі; зміни трудової етики молодих людей тощо. Цікавими, на наш погляд, є твердження К. Роджерса ("Freedom to learn for the 80's") про те, що регуляторами поведінки особистості є іiі спроможність рости, розвиватись і навчатися 3 опорою на власний досвід. На його думку, неможливо змінити людину лише шляхом передачі їй готового досвіду, проте слід створити умови, за яких особистість буде розвиватися. Створення такого середовища дослідник називає "полегшенням", а модель, запропонована автором книги, отримала назву Person Centered Approach - концентрація на особистості (McLeod, 2019).
Критеріями професіоналізму майбугніх медичних працівників як показників професійної компетентності виступають: рівень професійних знань і якостей; рівень "надпрофесійних" знань та сформованих якостей; рівень сформованості позитивної "Я-концепції"; прагнення до професійного та кар'єрного зростання. Професійна компетентність визначає ефективність медичної практики фахівця, здатність його до впровадження інновацій та особистісного саморозвитку.

Висновки та перспективи подальших досліджень. Основною умовою розвитку особистості майбутнього медичного працівника є переорієнтація освітнього процесу ЗВМО з вузько-предметного характеру викладу і вивчення навчальних дисциплін на професійно зорієнтований з урахуванням реальних потреб практики. Відповідно до концептуальних положень нормативно-правової бази щодо євроінтеграції сучасний зміст освіти набуває ознак багатокомпонентності, включаючи не лише знання, а і способи практичної діяльності, творчий досвід, ціннісні орієнтації особистості, що забезпечують відповідний рівень фахової компетентності. Таким чином, оновлення системи професійної підготовки фахівців медичної галузі нової формації потребує розвитку професійної компетентності, належного професійного рівня, що, у свою 
чергу, слугують підвищенню ефективності адаптації до професійного середовища, динаміки сучасних реалій.

У процесі формування професійної компетентності особливу увагу варто приділити спрямованості особистості майбутнього медичного працівника - мотиви, потреби й суспільні вимоги, що є регуляторами поведінки, вибору ціннісних орієнтирів. Підгрунтям професійної спрямованості виступає інтерес з боку майбутнього медичного працівника до обраної професії, що відображається у ставленні до колег, пацієнтів, адміністрації медичного закладу, медичної практики в цілому, прагненні самоосвіти та самовдосконалення тощо. Лише за таких умов можна стверджувати про те, що професійна компетентність буде сформована на належному рівні, що дасть змогу медичному працівнику якісно надавати медичні послуги.

\section{СПИСОК ЛІТЕРАТУРИ}

Академічний тлумачний словник в 11 томах. (1973). Т. 4.

Лазоришинець, В. В., Банчук, М. В., Волосовець, О. П. (2008). Вища медична освіта на сучасному етапі. Проблеми сучасної медичної науки та освіти, 2, 5-10.

Вознюк, О. В. (2011). Сучасні наукові підходи як методологічні засади компетентнісного підходу в освіті. Професійна педагогічна освіта: компетентнісний підхід. Житомир : Видво ДУ ім. І. Франка.

Кульчицький, В. (2012). Особливості формування професійної компетентності особистості студента-медика. Молодь і ринок, 5 (88), 91-94.

Кремень В. Г. (Ред.). Енциклопедія освіти. (2008). Київ : Юрінком Інтер.

Зимняя, И. А. (2006). Общая культура и социальная компетентность человека. Эйдос. Взято $3 \mathrm{http} / /$ www.eidos.ru/journal/2006/0504

Кошель, В. И. (2015). Бально-рейтинговая система оценки компетенции как фактор мотивации в формировании профессиональной готовности выпускника медицинского вуза. Медицинское образование и вузовская наука, 1 (7), 20-25.

Крамаренко, С. (2010). Креативна інноваційна особистість - мета нової гуманістичної освіти. Нива знань, 3 , 35-36.

Крицький, I. О., Гощинський, П. В та ін. (2018). Формування професійної компетентності майбутнього лікаря на прикладі студентів медичного фракультету ТДМУ. Медична освіта, 3, $44-47$.

Куклін, О. В. (2008). Економічні аспекти вищої освіти. Київ : Знання України

Про основні компетенції для навчання протягом усього життя. Рекомендація Свропейського Парламенту та Ради (СС) від 18.12.2006. Взято 3 https://zakon.rada.gov.ua/laws/show/ 994975

Савченко, О.П.(2010). Компетентнісний підхід у сучасній вищій школі. Педагогічна наука: історія, теорія, практика, тенденииї розвитку, 3, 10-18.

Ann, K. Allen (2012). Research skills for Medical Students. SAGE Publication Inc.

Willison, J. (2009). A handbook for research skills development and assessment in the curriculum.

McLeod, S. A. (2019). Терапія, орієнтована на особи. Просто психологія, 2019. Взято $3 \mathrm{https}: / /$ www.simplypsychology.org/clientcentred-therapy.html

Budnyk, O. (2019). Innovative Competence of a Teacher: best European Practices. Journal of Vasyl Stefanyk Precarpathian National University, 6 (1), 76-89. DOI 10.15330/jpnu.6.1.76-89.

Про внесення змін до деяких законодавчих актів України щодо удосконалення законодавства 3 питань діяльності закладів охорони здоров'я. Закон України. (2017). Взято $3 \mathrm{https://}$ zakon.rada.gov.ua/laws/show/2002-19

\section{REFERENCES}

Akademichnyi tlumachnyi slovnyk v 11 tomakh. (1973). T. 4.

Lazoryshynets, V. V., Banchuk, M. V., Volosovets, O. P. (2008). Vyshcha medychna osvita na suchasnomu etapi. Problemy suchasnoi medychnoi nauky ta osvity, 2, 5-10.

Vozniuk, O.V. (2011). Suchasni naukovi pidkhody yak metodolohichni zasady kompetentnisnoho pidkhodu v osviti. Profesiina pedahohichna osvita: kompetentnisnyi pidkhid. Zhytomyr : Vyd-vo ZhDU im. I. Franka.

Kulchytskyi, V. (2012). Osoblyvosti formuvannia profesiinoi kompetentnosti osobystosti studenta-medyka. Molod $i$ rynok, 5 (88), 91-94.

Kremen V. H. Entsyklopediia osvity. (2008). Kyiv : Yurinkom Inter.
Zimnyaya, I. A. (2006). Obschaya kultura i sotsialnaya kompetentnost cheloveka. Eydos. Retrieved from http// www.eidos.ru/journal/2006/0504

Koshel, V. I. (2015). Balnoreytingovaya sistema otsenki kompetentsii kak faktor motivatsii $\mathrm{v}$ formirovanii professionalnoy gotovnosti vyipusknika meditsinskogo vuza. Meditsinskoe obrazovanie $i$ vuzovskaya nauka, 1 (7), 20-25.

Kramarenko, S. (2010). Kreatyvna innovatsiina osobystist - meta novoi humanistychnoi osvity. Nyva znan, 3, 35-36.

Krytskyi, I. O., Hoshchynskyi, P. V. ta in. (2018). Formuvannia profesiinoi kompetentnosti maibutnoho likaria na prykladi studentiv medychnoho fakultetu TDMU. Medychna osvita, 3, $44-47$.

Kuklin, O. V. (2008). Ekonomichni aspekty vyshchoi osvity. Kyiv : Znannia Ukrainy.

Rekomendatsiia Yevropeiskoho Parlamentu ta Rady (IeS) "Pro osnovni kompetentsii dlia navchannia protiahom usoho zhyttia" vid 18.12.2006. Retrieved from https://zakon.rada.gov.ua/laws/ show/994_975

Savchenko, O. P. (2010). Kompetentnisnyi pidkhid u suchasnii vyshchii shkoli. Pedahohichna nauka: istoriia, teoriia, praktyka, tendentsii rozvytku, 3, 10-18.

Ann, K. Allen. (2012). Research skills for Medical Students. SAGE Publication Inc.

Willison, J. (2009). A handbook for research skills development and assessment in the curriculum. Centre for Learning and Professional Development University of Adelaide.

McLeod, S. A. (2019). Терапія, орієнтована на особи. Просто психологія, 2019. Retrieved from https:// www.simplypsychology.org/clientcentred-therapy.html

Budnyk, O. (2019). Innovative Competence of a Teacher: best European Practices. Journal of Vasyl Stefanyk Precarpathian National University, 6(1), 76-89. DOI 10.15330/jpnu.6.1.76-89.

Pro vnesennia zmin do deiakykh zakonodavchykh aktiv Ukrainy shchodo udoskonalennia zakonodavstva $\mathrm{z}$ pytan diialnosti zakladiv okhorony zdorovia. Zakon Ukrainy. (2017). Retrieved from https:// zakon.rada.gov.ua/laws/show/2002-19

Стаття надійшла 12.03 .2020 р. 